\title{
Effect of Bio-fertilizers and Organic Amendments on Nutrient Uptake and Soil Microbial Population of Pummelo Seedlings (Citrus maxima L) under Nursery Condition
}

\author{
Aziz Fayaz, S. V. Patil*, G. S. K. Swamy, T. H. Shankarappa and B. R. Premalatha \\ College of Horticulture, UHS campus, GKVK, Bengaluru-560 065, Karnataka, India \\ *Corresponding author
}

\section{A B S T R A C T}

Ke y w o r d s
Nitrogen,
Phosphorus,
Potassium, Bio-
fertilizers, Organic
amendments

An experimental was carried out at Regional Horticultural Research and Extension Centre (RHREC), University of Horticultural sciences campus, GKVK, post Bangaluru-560065, during the year $2019-20$ ). The nursery was established in potting mixture; sand, soil and farm yard manure in the ratio of 2:1:1 (Sand: Soil: FYM;) taken in polythene bags of size $12 \mathrm{~cm} \times 24 \mathrm{~cm}$. Applied with bio-fertilizers such as Azospirillum spp., Phosphorus solubilizing bacteria (PSB), Pseudomonas flourescens and Vesicular Arbuscular Mycorrhiza (VAM)@6 g per plant soil based bio-fertilizers. Organic amendments such as Panchagavya, Jeevamrutha, Beejamrutha and bio-digested liquid were tested at 5 and 10 per cent (applied through foliar application at 30 days interval). A total of nine treatments were tested in four replications. The results at the end of 120 days showed that the combination of four bio-fertilizers; Azospirillum, Phosphorus solubilizing bacteria, Pseudomonas flourescensand VAM had highest Nitrogen per plant $(0.636 \mathrm{~g})\left(\mathrm{T}_{5}\right)$. However $\mathrm{T}_{3}$ treatment had maximum Phosphorus $(0.055 \mathrm{~g} / \mathrm{plant})$ and Potassium $(0.150$ g/plant) with inoculation of Azospirillum + PSB+VAM. The maximum bacterial population (4.40 CFU X $10^{4} \mathrm{~g}^{-1}$ soil) was found in the treatment Azospirillum spp. + PSB $+\mathrm{PF}+\mathrm{VAM}\left(\mathrm{T}_{5}\right)$, followed by $\mathrm{T}_{3}\left(3.75 \mathrm{CFU} \mathrm{X} 10^{4} \mathrm{~g}^{-1}\right.$ soil). The highest fungal population (2.60 CFU X $10^{4} \mathrm{~g}^{-1}$ soil) was noticed in the treatment Azospirillum spp. + PSB) + VAM $\left(\mathrm{T}_{2}\right)$, followed by $\mathrm{T}_{5}\left(2.55 \mathrm{CFU} \times 10^{4} \mathrm{~g}^{-1}\right.$ soil $)$, the minimum NPK and microbial population was recorded in control treatment at the end of 120 days in nursery.

\section{Introduction}

The Pummelo (Citrus maxima or citrus grandis) is the largest fruit among Citrus fruits. It has thickrind and locally it is known as Chakotha, Chakotara etc. In India this fruit is commercially grown on avery limited scale but the trees are found in North Eastern states, North Western Himalayan region, Eastern
Uttar Pradesh, Bihar, Karnataka and Kerala. It is used in religious programmes in the country. Pummelo has good nutrition value. It is rich in potassium, fiber and calcium, and pummelo contain vitamin $\mathrm{A}, \mathrm{B}$ and $\mathrm{C}$ and it is an excellent source of potassium. The pummelo are rich in thiamine (B1), riboflavin (B2) and niacin (B3).It is known to help in cases of fever, sore throat, pancreatic cancer, 
insomnia, diabetes, fatigue, stomach and also contains some medicinal properties. Pummelo grow in Kerala and Karnataka. The mainly states such as Manipur, Tripura and Assam cultivate the pummelo up to 1,500 meters MSL. The major diseases of pummlo are crown rot, root rot, Scab, Powdery Mildew, gummosis and citrus greening. The major pests are scale, citrus leaf miner, aphids and soft green reported by (Sankar et al., 2014).Efforts in development of pummelo plantation are directed at the availability of superior cultivars that produce adequate flowering to ensure high productivity and fruit quality. Superior cultivars can be obtained through germplasm selection, crossing and biotechnology utilization. Identification of differences among pummelo accessions can be seen based on the characteristics of the fruit, including size and shape of the fruit, seed number, color and texture of flavedo (epicarp), thickness and color of albedo (mesocarp), color and flavor fruit flesh, and aroma of essential oil. This research was done to observe growth and quality of the fruit of three pummelo accessions (Susanto et al., 2018). Pummelo is a tropical citrus fruit. It is known for its large size fruit, with $15-25 \mathrm{~cm}$ in diameter and weighs around is $1-2 \mathrm{~kg}$. The plant is spiny if propagated from seed or spineless if propagated vegetative. Its major producer is China followed by United States of America. India is in seventh position having an area of 12,400 ha, with a production of $2,85,324$ tons and productivity of $23.01 \mathrm{t} / \mathrm{ha}$ (Anonymous $e t$ al., 2013). In India it is grown in far northeastern regions (such as Manipur and West Bengal), and some southern regions such as Karnataka (Bengaluru) and Kerala.

Application of bio-fertilizers helps to improve the soil fertility and crop productivity in several crops through atmospheric nitrogenfixation, solubilizing insoluble phosphorus and other nutrients. It also improves the seed germination, root proliferation, synthesis of plant growth substances and suppresses the plant diseases (Verma et al., 1993). Azospirillum is a non-symbiotic micro aerophilic bacterium commonly found in association with roots of horticultural crops. It has useful characters like high nitrogen fixation capacity and tolerance to high soil temperature. It is nitrogen in the range of $10-$ $40 \mathrm{~kg}$ per hectare, and also in saving inputs of nitrogenous fertilizers by $20-30 \%$. It is also well suited for plants raised through nursery. The phosphate solubilizes included bacteria or fungi but change insoluble form of phosphate to soluble form by producing organic acids. In general about $15-25 \%$ of insoluble phosphate can be solubilized. These fertilizers play important role in solubilizing insoluble phosphate. About 95-99 percent of the total soil phosphorus is insoluble which are indirectly available to the plants. Several soil bacteria; particularly Pseudomonas and Bacillus and fungi Pencillium and Aspergillus possess the ability to bring insoluble phosphate in soil into soluble forms by secreting organic acids such as acetic, formic, propionic, lactic, glycolic, numeric and succinic acids. Their inoculum is available in packets of $200 \mathrm{~g}$ similar to that of Rhizobium. They can be mixed with FYM and applied to soil (SankaraRao Karri et al., 2012).

\section{Materials and Methods}

The experiment on influence of biofertilizers and organic amendments on nutrient uptake and soil microbial population of Pummelo seedlings (Citrus maxim CV. Devanahalli) under nursery condition was conducted in poly house at Regional Horticultural Research and Extension Centre, University of Horticultural sciences campus, GKVK, Bangalore 560065 during the period 2019-20.

Pummelo seeds were collected from pummelo plot of RHREC. Seedlings were raised in 
polythene bags of $(12 \times 24) \mathrm{cm}$ with 4 holes punched on the polythene bags from bottom to top to facilitate proper drainage. Then the seeds were sown into the media polybags containing mixtures of Soil, FYM and Sand $(2: 1: 1)$ and treated with biofertilizers combinations such as Azospirillum sp, Phosphorus solubilizing bacteria (PSB), Pseudomonas fluorescence (PF) and Vesicular Arbuscular Mycorrhiza (VAM) @ $6 \mathrm{~g}$ per seedling (all together) per treatment, these polythene bags were kept under polyhouse.at 30 days interval liquid organic manure spanchagavya, jeevamrutha, beejamrutha and bio digester @ 5, 10, 10 and 10 per cent, respectively were applied through foliar application. And observations were recorded at 120 days after germination.

\section{The experiment included nine treatments} as follows

T1 Water Spray (control)

T2 Azospirillum spp. + Phosphorus solubilizing bacteria (PSB) + Pseudomonas fluorescens (PF) (2 g each)

T3 Azospirillum spp. +Phosphorus solubilizing bacteria (PSB) + Vesicular Arbuscular Mycorrhiza (VAM) (2 g each)

T4 Azospirillum spp. + Pseudomonas fluorescens $(\mathrm{PF})+$ Vesicular Arbuscular Mycorrhiza (VAM) (2 g each)

T5 Azospirillum spp. + Phosphorus solubilizing bacteria (PSB) + Pseudomonas fluorescens (PF)+Vesicular Arbuscular Mycorrhiza (VAM)(1.5 g each)

T6 Panchagavya Spray @ 5\% after germination

T7 Jeevamrutha Spray @ $10 \%$ after germination
T8 Beejamrutha Spray @ 10\% after germination

T9Biodigested liquid Spray @ 10\% after germination

\section{Results and Discussion}

The results in Table 1 (Fig. 1) showed the highest nitrogen uptake $(0.636 \mathrm{~g})$ was recorded in the treatment Azospirillum, Phosphorus solubilizing bacteria (PSB), Pseudomonas fluorescens (PF) and Vesicular Arbuscular Mycorrhiza (VAM) it was on par the Azospirillum, Phosphorus solubilizing bacteria (PSB) and Vesicular Arbuscular Mycorrhiza (VAM)(0.575 g), whereas the maximum phosphorus uptake $(0.055 \mathrm{~g})$ and potassium uptake $(0.150 \mathrm{~g})$ per plant was found in the treatment Azospirillum, PF and VAM and it was on par with consortia that contained combinations of Azospirillum, Pseudomonas fluorescens (PF) and VAM. While the minimum nutrient uptake was recorded un-inoculated control.

The results in Table 2 (Fig. 2) indicates the maximum bacterial population (4.40 CFU X $10^{4} \mathrm{~g}^{-1}$ soil) was found in the treatment Azospirillum spp. $+\mathrm{PSB}+\mathrm{PF}+\mathrm{VAM}\left(\mathrm{T}_{5}\right)$, followed by $\mathrm{T}_{3}\left(3.75 \mathrm{CFU} \times 10^{4} \mathrm{~g}^{-1}\right.$ soil). The highest fungal population $\left(2.60 \mathrm{CFU} \mathrm{X} 10^{4} \mathrm{~g}^{-}\right.$ ${ }^{1}$ soil) was noticed in the treatment Azospirillum spp. + PSB) + VAM $\left(\mathrm{T}_{2}\right)$, followed by $\mathrm{T}_{5}\left(2.55 \mathrm{CFU} \times 10^{4} \mathrm{~g}^{-1}\right.$ soil $)$ and minimum total microbial population was recorded in $\mathrm{T}_{1}$ treatment control i.e., water spray.

The evaluation of biofertilizers on nitrogen fixer, phosphate solubilizer, biocontrol agent and phosphorous mobilize in the form of Azospirillum spp., Pseudomonas striata, Pseudomonas fluorescens and VAM respectively had increased nutrient uptake of mango grafts seedlings var. Alphonso under 
poly-house condition. Nutrient uptake was significantly superior reported by (Shankarappa et al., 2018).

The effect of farmyard manure and biofertilizers on leaf $\mathrm{N}, \mathrm{P}, \mathrm{K}, \mathrm{Fe}, \mathrm{Mn}$ and $\mathrm{Zn}$ content of Eureka lemon trees. Leaf nitrogen content increased with the application of different treatments as compared to control. The maximum leaf nitrogen content was recorded with combination of $75 \%$ NPK + $27.5 \mathrm{~kg}$ farmyard manure + Azotobacter $25 \mathrm{~g}+$ Azospirillum $25 \mathrm{~g}+$ Bacillus circulans $25 \mathrm{~g}$ and followed by the $50 \% \mathrm{NPK}+55 \mathrm{~kg}$ farmyard manure + Bacillus circulans $25 \mathrm{~g}$ and $75 \% \mathrm{NPK}+27.5 \mathrm{~kg}$ farmyard manure + Azotobacter 25g. The significant effect of NPK in combination with farmyard manure and biofertilizers was noted on the nitrogen content of Eureka lemon leaves. Exhibited maximum phosphorus content without significant differences.
This may be due to presence of organic manures increased microorganisms population and organic acids which cause better availability of soil phosphorus and better plant uptake, with regard to potassium. This may be due to the balanced nutrients which encourage potassium uptake. These result agree with those obtained by (Sharaf $e t$ al., 2011) and El-Sheikh, (2014) on Washington navel orange and lemon trees. These result could be attributed to Azotobacter, Azospirillum, Bacillus megatherium and Bacillus circulans by increasing leaf nitrogen, phosphorus and potassium content which indicated that the biofertilizers might have created certain microbial environment in the root rhizosphere zone for better uptake of NPK. Such conclusion was confirmed by (Srivastava $e t$ al., 2002).

Table.1 Effect of bio-fertilizers and organic amendments on NPK uptake by plant of pummelo seedlings at $120 \mathrm{DAG}$

\begin{tabular}{|c|c|c|c|}
\hline Treatments & $\begin{array}{l}N \text { uptake } \\
\left(g^{-1} \text { plant }\right)\end{array}$ & $\begin{array}{l}\text { P uptake } \\
\left(\mathrm{g}^{-1} \text { plant }\right)\end{array}$ & $\begin{array}{l}\mathrm{K} \text { uptake } \\
\left(\mathrm{g}^{-1} \text { plant }\right)\end{array}$ \\
\hline$T_{1}$. Water Spray (control) & 0.325 & 0.029 & 0.086 \\
\hline 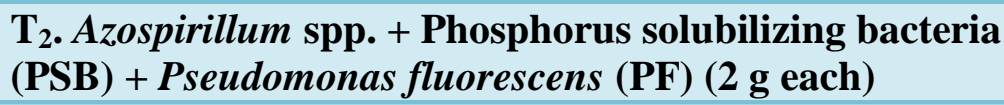 & 0.395 & 0.039 & 0.107 \\
\hline $\begin{array}{l}\text { T}_{3} \text { Azospirillum spp. + Phosphorus solubilizing bacteria } \\
\text { (PSB) + Vesicular Arbuscular Mycorrhiza (VAM)( } 2 \mathrm{~g} \\
\text { each) }\end{array}$ & 0.575 & 0.055 & 0.150 \\
\hline 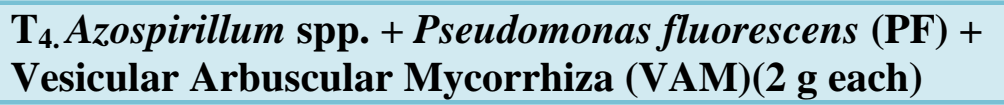 & 0.519 & 0.053 & 0.137 \\
\hline $\begin{array}{l}\text { T. Azospirillum spp. + Phosphorus solubilizing bacteria } \\
\text { (PSB) + Pseudomonas fluorescens }(\mathrm{PF})+\mathrm{PF}+\text { Vesicular } \\
\text { ArbuscularMycorrhiza (VAM) (1.5 g each) }\end{array}$ & 0.636 & 0.045 & 0.134 \\
\hline $\mathrm{T}_{6 .}$ Panchagavya Spray @ 5\% aftergermination & 0.463 & 0.042 & 0.112 \\
\hline$T_{7 .}$ Jeevamrutha Spray @ 10\% after germination & 0.467 & 0.040 & 0.123 \\
\hline T8. Beejamrutha Spray @ 10\% after germination & 0.484 & 0.042 & 0.130 \\
\hline $\mathrm{T}_{9}$. Biodigested liquid Spray @ 10\% after germination & 0.407 & 0.038 & 0.114 \\
\hline SE.m \pm & 0.009 & 0.001 & 0.001 \\
\hline CD at $5 \%$ & 0.027 & 0.003 & 0.004 \\
\hline
\end{tabular}

DAG.* Days after germination 
Table. 2 Effect of bio-fertilizers and organic amendments on soil microbial population at $120 \mathrm{DAG}$

\begin{tabular}{|c|c|c|}
\hline Treatments & $\begin{array}{c}\text { Total bacteria } \\
\text { (CFU X } 10^{4} \mathrm{~g}^{-1} \text { soil) }\end{array}$ & $\begin{array}{l}\text { Total fungi count } \\
\text { (CFU X } 10^{4} \mathrm{~g}^{-1} \text { soil) }\end{array}$ \\
\hline $\mathbf{T}_{1}$. Water Spray (control) & 2.27 & 1.40 \\
\hline $\begin{array}{l}\text { T}_{2 .} \text { Azospirillum spp. + Phosphorus solubilizing } \\
\text { bacteria (PSB) + Pseudomonas fluorescens (PF) ( } 2 \text { g } \\
\text { each) }\end{array}$ & 3.07 & 2.60 \\
\hline $\begin{array}{l}\text { T }_{3 .} \text { Azospirillum spp. + Phosphorus solubilizing } \\
\text { bacteria (PSB) + Vesicular Arbuscular Mycorrhiza } \\
\text { (VAM)(2 g each) }\end{array}$ & 3.75 & 2.47 \\
\hline $\begin{array}{l}\text { T4. Azospirillum spp. + Pseudomonas fluorescens } \\
\text { (PF) + Vesicular ArbuscularMycorrhiza (VAM)(2 g } \\
\text { each) }\end{array}$ & 3.30 & 2.42 \\
\hline $\begin{array}{l}\text { T5.Azospirillum spp. + Phosphorus solubilizing } \\
\text { bacteria (PSB) + Pseudomonas fluorescens (PF) +PF } \\
\text { + Vesicular Arbuscular Mycorrhiza (VAM) }(1.5 \mathrm{~g} \\
\text { each) }\end{array}$ & 4.40 & 2.55 \\
\hline T6.Panchagavya Spray @ 5\% after germination & 3.00 & 2.40 \\
\hline $\mathbf{T}_{7 .}$ Jeevamrutha Spray @ 10\% after germination & 2.67 & 2.05 \\
\hline T. Beejamrutha Spray @ 10\% after germination & 3.05 & 2.12 \\
\hline $\begin{array}{l}\text { T9. Biodigested liquid Spray @ } 10 \% \text { after } \\
\text { germination }\end{array}$ & 2.75 & 1.80 \\
\hline SE.m \pm & 0.18 & 0.11 \\
\hline CD at $5 \%$ & 0.54 & 0.33 \\
\hline
\end{tabular}

DAG.* Days after germination

Fig.1 Effect of bio-fertilizers and organic amendments on NPK uptake by plant of pummelo seedlings at $120 \mathrm{DAG}$

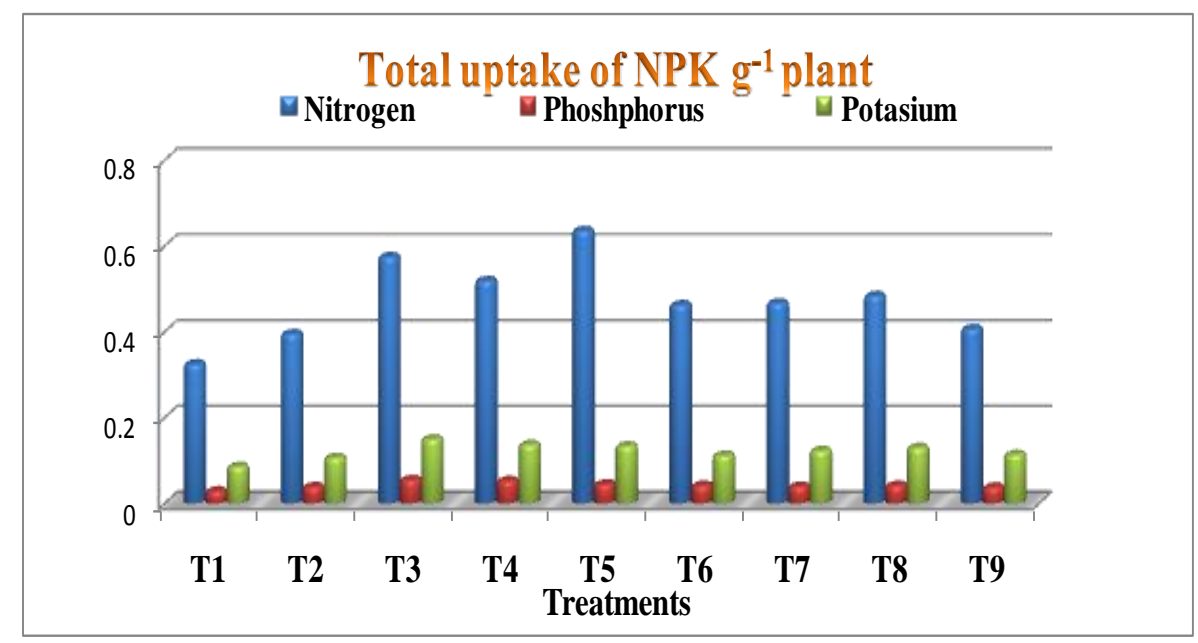

DAG.* Days after germination 
Fig.2 Effect of bio-fertilizers and organic amendments on soil microbial population at 120 DAG

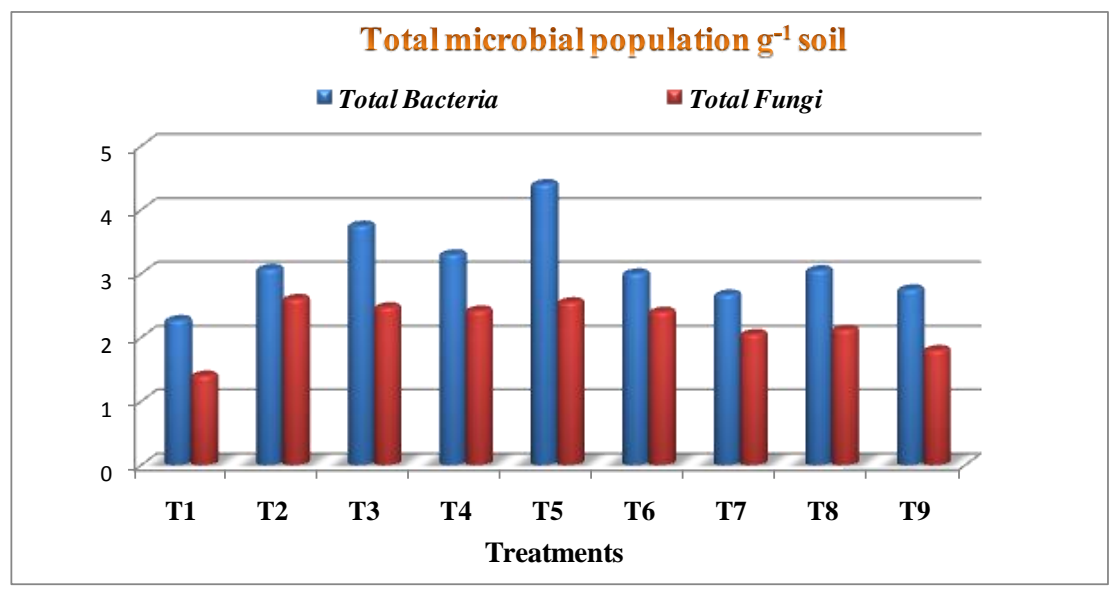

DAG.* Days after germination

As regard to micronutrients showed that the uptake of Fe and Mn were improved with the application of $75 \% \mathrm{NPK}+27.5 \mathrm{~kg}$ farm yard manure + Azotobacter $25 \mathrm{~g}+$ Azospirillum $25 \mathrm{~g}$ + Bacillus circulans25g. While, the $\mathrm{Zn}$ content uptake was improved with the application of $50 \% \mathrm{NPK}+55 \mathrm{~kg}$ farmyard manure + Bacillus circulans $25 \mathrm{~g}$ and $75 \%$ $\mathrm{NPK}+27.5 \mathrm{~kg}$ farmyard manure + Azotobacter $25 \mathrm{~g}$. These findings are in line with those of (Selvamani and Manivannan, 2009).

The inoculated pots had been colonized greatly with AM fungi ( $50 \%)$, while much less root colonization with AM fungi ( 10\%) has been noted in the control plants. Addition of phosphorus increased sour orange shoot and root DM of both mycorrhizal and uninoculated plants, although, the pattern of growth response were affected by Phosphorus levels. inoculation with AM fungi increased shoot DM at low and moderate phosphorus rates (15 and $45 \mathrm{mg} \mathrm{P} \mathrm{kg-1}^{1}$ ), while, at high phosphorus rate (90 $\mathrm{mg} \mathrm{P} \mathrm{kg-1}^{1}$ ), the beneficial effect of AM fungi inoculation was low reported by (Al Karaki., 2002). Considering that potassium and phosphorus was applied at recommended rates, it is possible that their uptake was enhanced by nitrogen fertilizers which have been reported by mediate the uptake and utilization of potassium, phosphorus and other elements in plants (Brady et al., 1984).

The inoculated bacteria were able to persist in the rhizosphere of aonla. In all the treatments population of Azotobacter, phosphate solubilizing bacteria and P.maltophilia was higher than at the time of sowing. Highest population of Azotobacter (6.501 CFU/g), PSB (7.175 CFU/g) and P.maltophilia (7.761 $\mathrm{CFU} / \mathrm{g}$ ) was observed in vermicompost enriched Azotobacter + PSB + PM4 + AM fungi. These populations were significantly more than the control as well as other treatments reported by (NeetuKhare et al., 2018).

The higher $\mathrm{N}$ uptake was observed in the treatment where Azospirillum was used with either $100 \%$ or $75 \%$ recommended dose of inorganic fertilizers. $\mathrm{P}$ uptake was higher in the treatments where PSB and VAM were used. Lin and Fox (1992) also reported increased $\mathrm{P}$ uptake in pot cultured banana in response to mycorrhizal application. In general, higher NPK uptake was observed in the treatments where combination of biofertilizers was applied with $100 \%$ or $75 \%$ 
recommended dose of inorganic fertilizers. (Shaimaa, 2017) Reported that biofertilizers combined with mineral fertilizer had more positive effects than both microbial inoculants solely and non-inoculated control. Azotobacter + AM at $75 \%$ induced significant increment in growth criteria leaf $\mathrm{N}, \mathrm{P}$ and $\mathrm{K}$ contents, biofertilizers only. Finally, a similar trend was observed regarding the total population of both microbial and Aozotobacter in the rhizosphere region of orange tree, where Azotobacter + AM at 75 and $50 \%$ NP stimulated the highest number of total microbial or Azotobacter counts and nitrogenizes activity. On the other hand, the colonization percentage of AMF and number of spores/g soil, as well as the enzyme activities of both dehydrogenase and phosphatase attained higher values from using Azotobacter + AM integrated with 50 and $25 \%$ NP application as compared to unioculated control and biofertilizers singly.

In conclusion the highest nitrogen uptake was recorded with combination of Azospirillum spp. + Phosphorus solubilizing bacteria (PSB) + Pseudomonas flourescens (PF) and VAM, however the maximum phosphorus and potassium uptake in the treatment Azospirillum spp. + Pseudomonas flourescens (PF) and VAM. Significantly higher bacterial population was found in the treatment Azospirillum spp. + PSB +PF + VAM, while the highest fungal population was noticed in the treatment Azospirillum spp. + PSB) + VAM at the end of 120 days in experiment.

\section{References}

Al-Karaki, G. N., 2002, Field response of garlic inoculated with arbuscular mycorrhizal fungi to phosphorus fertilization. J. Plant Nutrition, 25: 747-756.

Anonymous., 2013, Embrapa, Mandioca $e$ fruitcultura.
El Sheikh, A.F., 2014, Effect of some biological fertilizers on productivity and postharvest fruit quality of Adalia lemons grown in the United Arab Emirates. Acta. Hort.1047 (1):45 50.

Ennab, H. A., 2016, Effect of Organic Manures, Biofertilizers and NPK on Vegetative Growth, Yield, Fruit Quality and Soil Fertility of Eureka Lemon Trees (Citrus limon (L.) Burm). J. Soil Sci. and Agri. Eng., Mansoura Univ., 7(10): 767- 774.

Gaikwad, R. T., Balerao, V. P., Pujari, C. V. and Patil, N. M., 2010, Effect of biofertilizers on nutrient uptake and yield attributes of banana. Asian $J$. Soil Sci., 4(2): 271-274.

Ghazi, N., 2013, Effect of arbuscular mycorrhizal fungi on establishment of sour orang (Citrus aurantium). Jordan Univ of Sci\& Technology Irbid. 984:103-108.

Lin, M. L. and Fox, R. L., 1992), the comparative agronomic effectiveness of rock phosphate and super phosphate for banana. Fert. Res., 31(2): 131-135.

Malik Asif, Mughal, A. H., Bisma, R., Zaffar Mehdi., Saima, S., MisbahAjaz., Malik, M. A., Amjad Masood and Showkat Sidique., 2018, Application of Different Strains of Biofertilizers for Raising Quality Forest Nursery. Int. J. Curr. Microbiol. Sci., 7(10): 3680-3686.

NazikHaki Khalil1 and Raed Jamel Agah., 2017, Effect of Chemical, Organic and Bio fertilization on Growth and Yield of Strawberry Plant. Int. J. Advances in Chemical Engg., \& Bio. Sci., 4.

NeetuKhare, Pathak, D. V. and Mukesh Kumar., 2018, Microbially Enriched Vermicompost Affecting Seedling and Plant Growth in Aonla and Bael. 
Int. J. Curr. Microbiol. App. Sci., 7(4): 2664-2672.

Sankar, V., Tripathi, P. C., Karunakaran, G. and Senthilkumar, R., 2014, Pummelo cultivation. Indian Institute. Hort. Res., 04.1. 37-54.

SankaraRao Karri., 2012, Role of bio fertilizers in horticulture crops.J. Plant Development. Sci., 4 (1): 125129.

Selvamani, P. and K. Manivannan, K., 2009, Effect of organic manures, inorganic fertilizers and biofertilizers on the nutrient concentration in leaves at different growth stages of banana cv. Poovan. J. Phytology, 1(6): 381 387.

Shaimaa, A., Mohamed and Massoud, O.N., 2017, Impact of Inoculation with Mycorrhiza and Azotobacter under Different N and P Rates on Growth, Nutrient status, Yield and Some Soil Characteristics of Washington Navel Orange Trees. Middle East J. Agri., 06: 03 .

Shankarappa, T. H., Narayana Ready, Subramanyam, B., Sreenatha, A. and Aswathanarayana, N., 2018, Bio- fertilizers for growth and establishment of alphonso mango graft under nursery condition. Int. $J$. Curr. Microbiol. App. Sci., 7: 52055211

Sharaf, M.M., K.A. Bakry and S.F. ELGioushy., 2011, influence of some bio and organic nutritive addenda on growth, productivity, fruit quality and nutritional status of Washington navel orange trees. Egypt J. Appl. Sci., 26(9): $253-268$.

Srivastava, A.K., 2012, Integrated nutrient management. In: Advances in Citrus Nutrition. pp. $369-389$.

Susanto, S., Hermansah, D. and Amanda, F., 2018 , the growth and quality of fruit of three pummelo (Citrus maxima (Burn.) Merr.) Accessions. IOP Conf. Series: Earth and Environmental. Sci., 196, 012014.

Verma, L.N., 1993, Bio-fertilizers in Agriculture in Organics in soil health and crop production. Thampan, P.K. (Ed.) Peekay Tree Crops Development Foundation, Cochin, Pp.151-184.

\section{How to cite this article:}

Aziz Fayaz, S. V. Patil, G. S. K. Swamy, T. H. Shankarappa and Premalatha, B. R. 2020. Effect of Bio-fertilizers and Organic Amendments on Nutrient Uptake and Soil Microbial Population of Pummelo Seedlings (Citrus maxima L) under Nursery Condition. Int.J.Curr.Microbiol.App.Sci. 9(10): 1592-1599. doi: https://doi.org/10.20546/ijcmas.2020.910.190 